\title{
PREVALENCE OF THROMBOCYTOSIS, THROMBOCYTOPENIA, LYMPHOCYTOSIS AND LYMPHOCYTOPENIA IN PATIENTS WITH LOWER RESPIRATORY TRACT INFECTION AND PATIENTS WITH URINARY TRACT INFECTION
}

\author{
Duygu Mert ${ }^{1}$ and Alparslan Merdin ${ }^{2}$ \\ ${ }^{1}$ University of Health Sciences, Ankara Dr. Abdurrahman Yurtaslan Oncology Training and Research Hospital, \\ Department of Infectious Diseases, Ankara, Turkey; \\ ${ }^{2}$ University of Health Sciences, Ankara Dr. Abdurrahman Yurtaslan Oncology Training and Research Hospital, \\ Hematology Clinic and Bone Marrow Transplantation Unit, Ankara, Turkey
}

\begin{abstract}
SUMMARY - There are many reasons for abnormal lymphocyte and platelet counts. In this study, we aimed to assess the prevalence of thrombocytosis, thrombocytopenia, lymphocytosis and lymphocytopenia in patients with lower respiratory tract infection (LRTI) and patients with urinary tract infection (UTI). This retrospective study included 52 LRTI patients and 60 UTI patients. Control group consisted of 70 healthy individuals admitted to the infectiology outpatient unit. No statistically significant relationship was found between the groups of subjects and platelet count. Seven (11.7\%) UTI patients and four (7.7\%) LRTI patients had lymphocytopenia but there was no statistically significant relationship between the groups of subjects and lymphocyte count. Study results suggested a conclusion that lymphocyte and platelet counts could be within the normal ranges in patients with UTI, as well as in those with LRTI.
\end{abstract}

Key words: Urinary tract infections; Respiratory tract infections; Thrombocytosis; Lymphocytosis; Platelet count

\section{Introduction}

Thrombocytopenia can be caused by many reasons. Drugs, infections and malignancy are some known agents that could have an association with thrombocytopenia. There is a decrease in platelet count due to immune attack in immune thrombocytopenia. Steroid treatment is the well-known initial treatment in immune thrombocytopenia. Eliminating the causative agent is an initial step in the management of thrombocytopenia induced by infections or drugs. Disseminat-

Correspondence to: Duygu Mert, $M D$, Sağlık Bilimleri Üniversitesi Ankara, Dr. Abdurrahman Yurtaslan Onkoloji Eğitim ve Araştırma Hastanesi, Yenimahalle, Ankara, Turkey

E-mail: drduygumert@hotmail.com

Received October 3, 2018, accepted March 26, 2019 ed intravascular coagulation, thrombotic thrombocytopenic purpura and hemolytic uremic syndrome are some other clinical situations that may result in thrombocytopenia. Many other reasons such as bone marrow failure and congenital diseases could be the etiology of thrombocytopenia. Peripheral smear is an initial step in the search for the etiology of thrombocytopenia. Pseudothrombocytopenia can also be easily differentiated from real thrombocytopenia by peripheral smear.

Thrombocytosis may be seen in myeloproliferative disorders. Kodali et al. and Cabello et al. have also reported thrombocytosis in some myelodysplastic syndrome patients ${ }^{1,2}$. Reactive thrombocytosis can be seen in iron deficiency anemia, infections and hyposplenism. Lymphocytosis can be found in hematologic malignancies such as chronic lymphocytic leukemia. Re- 
active lymphocytosis may also develop especially in viral infections. Lymphocytopenia can develop after chemotherapy and steroid treatment. Lymphocytopenia can also be seen in autoimmune diseases and infections.

Hereby, we aimed to assess the prevalence of thrombocytosis, thrombocytopenia, lymphocytosis and lymphocytopenia in patients with lower respiratory tract infection and patients with urinary tract infection.

\section{Patients and Methods}

Data on 70 patients with UTI and 67 patients with LRTI were recorded retrospectively from the electronic patient file database in 2017. Concomitant diseases in study patients were identified from the electronic database. All study patients were free from any cancer diagnosis record in the electronic database. Male patients with hemoglobin level $<13 \mathrm{mg} / \mathrm{dL}$ and female patients with hemoglobin level $<12 \mathrm{mg} / \mathrm{dL}$ were excluded from the study.

Patients with UTI were admitted to the infectiology outpatient unit between January 2, 2017 and March 10, 2017. Some of the patients had known comorbidities, some of which could have direct or indirect association with platelet levels. Treatments of some diseases might also have associations with platelet levels and functions. Therefore, three patients also suffering from chronic obstructive pulmonary disease (COPD), one patient with hepatitis B infection, one patient with systemic lupus erythematosus, one patient with multiple sclerosis (MS), two patients with thyroid diseases, one patient with Parkinson's disease and one patient with coronary artery disease were excluded from analysis. Consequently, 60 UTI patients were classified as UTI group.

Patients with LRTI were admitted to the infectiology outpatient unit between January 2, 2017 and March 24, 2017. Eight patients also suffering from COPD, one patient with Behçet's disease, two patients with asthma, two patients with Alzheimer's disease, one patient with cerebral palsy and one patient with cardiac rhythm disorder were excluded from the study. Consequently, 52 LRTI patients were classified as LRTI group.

Control group included 70 healthy individuals admitted to the infectiology outpatient clinic between
January 2, 2017 and April 7, 2017. These control subjects did not have any chronic disease records found in the electronic database at the time of outpatient clinic admission. These control subjects were also selected according to the aforementioned hemoglobin cut-off values determined for patients. All patients and control subjects were aged $\geq 18$ years. Patients aged $<18$ years were not included in the study.

Platelet counts $<150,000 / \mathrm{mm}^{3}$ were classified as thrombocytopenia and platelet counts $>450,000 / \mathrm{mm}^{3}$ as thrombocytosis. Lymphocyte counts $<1,000 / \mathrm{mm}^{3}$ were classified as lymphocytopenia and lymphocyte counts $>4,800 / \mathrm{mm}^{3}$ as lymphocytosis. A HORIBA Medical Pentra DF Nexus hematology analyzer (HORIBA ABX SAS, France) was the instrument to measure blood cells in patients admitted to the infectiology outpatient clinic. A written permission from the University of Health Sciences, Ankara Dr. Abdurrahman Yurtaslan Oncology Training and Research Hospital was obtained for the study.

The SPSS (IBM SPSS Statistics 20) for Windows was used on statistical analyses. Cross tabulation and Pearson's $\chi^{2}$-test were used for analysis of the relations between two qualitative variables. The level of statistical significance was set at $\mathrm{p}<0.05$. The study protocol was approved by the local hospital Ethics Committee (decision no.: 2017-11/02).

\section{Results}

The mean age of the UTI group patients and LRTI group patients was 53.9 and 51.9231 years, respectively. The mean age of control group subjects was 30.6964 years. Seven (11.7\%) UTI patients, four (7.7\%) LRTI patients and one (1.4\%) control subject had lymphocytopenia. On the other hand, one (1.6\%) UTI patient and one (1.9\%) LRTI patient had lymphocytosis. However, there was no statistically significant relationship between the groups and lymphocyte count ( $>0.05)$ (Table 1).

Four (6.7\%) UTI patients, five (9.6\%) LRTI patients and one (1.4\%) control subject had thrombocytopenia. In addition, two (3.8\%) LRTI patients and one (1.4\%) control subject but none of UTI patients had thrombocytosis. There was no statistically significant relationship between the groups and platelet count $(p>0.05)$ (Table 1). 
Table 1. Lymphocyte and platelet levels according to disease status

\begin{tabular}{|c|c|c|c|c|}
\hline & \multicolumn{3}{|c|}{ Disease status } & \multirow{2}{*}{$\begin{array}{l}\text { Statistica } \\
\text { analysis }\end{array}$} \\
\hline & UTI group $(n=60)$ & LRTI group $(\mathrm{n}=52)$ & Control group $(\mathrm{n}=70)$ & \\
\hline $\begin{array}{l}\text { Lymphocyte } \\
\text { Lymphocytopenia } \\
\text { Normal } \\
\text { Lymphocytosis }\end{array}$ & $\begin{array}{l}7(11.7 \%) \\
52(86.7 \%) \\
1(1.6 \%)\end{array}$ & $\begin{array}{l}4(7.7 \%) \\
47(90.4 \%) \\
1(1.9 \%)\end{array}$ & $\begin{array}{l}1(1.4 \%) \\
69(98.6 \%) \\
-\end{array}$ & $\begin{array}{l}\chi^{2}=7.061 \\
p=0.133\end{array}$ \\
\hline $\begin{array}{l}\text { Platelet } \\
\text { Thrombocytopenia } \\
\text { Normal } \\
\text { Thrombocytosis }\end{array}$ & $\begin{array}{l}4(6.7 \%) \\
56(93.3 \%) \\
-\end{array}$ & $\begin{array}{l}5(9.6 \%) \\
45(86.6 \%) \\
2(3.8 \%)\end{array}$ & $\begin{array}{l}1(1.4 \%) \\
71(97.3 \%) \\
1(1.4 \%)\end{array}$ & $\begin{array}{l}\chi^{2}=6.760 \\
p=0.149\end{array}$ \\
\hline
\end{tabular}

"Cross tabulation and Pearson's $\chi^{2}$-test were used for analysis of the relations between two qualitative variables; UTI $=$ urinary tract infection; LRTI = lower respiratory tract infection

\section{Discussion}

Güngör et al. found 25\% of LRTI patients to have thrombocytosis, and platelet counts $>500,000 / \mathrm{mm}^{3}$ were classified as thrombocytosis in their study ${ }^{3}$. We found $3.8 \%$ of our LRTI patients to have thrombocytosis. However, we analyzed platelet levels in 52 LRTI patients, whereas the above-mentioned study included 20 LRTI patients. In addition, we analyzed data on patients admitted to the infectiology outpatient unit, whereas Güngör et al. analyzed data on patients hospitalized in a pediatric inpatient unit ${ }^{3}$. Furthermore, Catal et al. showed the mean platelet count to be significantly higher in children with cultureproven upper UTI as compared to controls. $s^{4}$ We did not find any statistically significant relationship between the groups and platelet count. Additionally, Wyllie et al. report on the association between lymphocytopenia and bacteremia ${ }^{5}$, whereas de Jager $e$ t al. showed that lymphocytopenia could be useful to predict bacteremia ${ }^{6}$. In our study, the prevalence of lymphocytopenia was higher in the UTI group than in the LRTI group. However, we found no statistically significant relationship between the groups and lymphocyte count. On the other hand, bacteremia was not an inclusion criterion in our study.

We did not search for pseudothrombocytopenia in our study. Pseudothrombocytopenia is not a very frequent situation. Silvestri et al. report on the 15.3\% prevalence of ethylenediaminetetraacetic acid-dependent pseudothrombocytopenia among 111 patients referred to their outpatient clinic for isolated thrombocytopenia $^{7}$. Excluding pseudothrombocytopenia might increase accuracy in the studies assessing platelet levels in hemogram. There are many reasons affecting platelet and lymphocyte counts. We tried to exclude patients with known concomitant factors that could influence blood cell counts. However, these exclusions may not have been enough because of the retrospective design of the study. Further prospective studies that will exclude all concomitant effects can make more specific evaluations in this area.

In conclusion, lymphocyte and platelet counts might be within the normal ranges in patients with UTI, as well as in patients with LRTI.

\section{Acknowledgment}

We want to thank Melih Uzunoğlu from Gazi University for his support in statistical analysis. We also want to thank Prof. Mustafa Ertek and Dr. Fatma Avc1 Merdin for their support during the study.

\section{References}

1. Kodali D, Mesa H, Rawal A, et al. Thrombocytosis in myelodysplastic and myelodysplastic/myeloproliferative syndromes. Leukemia Lymphoma. 2007;48(12):2375-80. https://doi.org/ 10.1080/10428190701724827

2. Cabello AI, Collado R, Ruiz MA, Martínez J, Navarro I, Ferrer $\mathrm{R}$, Sosa AM, Carbonell F. A retrospective analysis of myelodysplastic syndromes with thrombocytosis: reclassification of the cases by WHO proposals. Leukemia Res. 2005 Apr;29 (4):365-70. https://doi.org/10.1016/j.leukres.2004.07.014

3. Güngör O, Meral C, Karademir F, Akcan AB, Aydınöz S, Kul M, Süleymanoğlu S. Alt solunum yolu enfeksiyonları ve üst üriner sistem enfeksiyonlarında trombositoz oranları ve değer- 
lendirilmesi. ADÜ Tıp Fakültesi Dergisi. 2011;12(2):1-3. (in Turkish)

4. Catal F, Bavbek N, Bayrak O, Uz E, Isik B, Karabel M, Degirmencioglu H, Mete E, Akcay A. Platelet parameters in children with upper urinary tract infection: is there a specific response? Ren Fail.2008;30(4):377-81. doi: 10.1080/08860220801947389

5. Wyllie DH, Bowler ICJW, Peto TEA. Relation between lymphopenia and bacteraemia in UK adults with medical emergencies. J Clin Pathol. 2004 Sep;57(9):950-5. doi: 10.1136/ jcp.2004.017335
6. de Jager CP, van Wijk PT, Mathoera RB, de Jongh-Leuvenink J, van der Poll T, Wever PC. Lymphocytopenia and neutrophillymphocyte count ratio predict bacteremia better than conventional infection markers in an emergency care unit. Crit Care. 2010;14(5):R192. doi: 10.1186/cc9309

7. Silvestri F, Virgolini L, Savignano C, Zaja F, Velisig M, Baccarani $\mathrm{M}$. Incidence and diagnosis of EDTA-dependent pseudothrombocytopenia in a consecutive outpatient population referred for isolated thrombocytopenia. Vox Sang. 1995;68(1):359. doi:10.1111/j.1423-0410.1995.tb02542.x

Sažetak

\section{UČESTALOST TROMBOCITOZE, TROMBOCITOPENIJE, LIMFOCITOZE I LIMFOCITOPENIJE U BOLESNIKA S INFEKCIJOM DONJIH DIŠNIH PUTOVA I BOLESNIKA S INFEKCIJOM MOKRAĆNOG SUSTAVA}

\section{Mert i A. Merdin}

Mnogo je razloga koji mogu poremetiti broj limfocita i trombocita. Cilj ovoga istraživanja bio je procijeniti učestalost trombocitoze, trombocitopenije, limfocitoze i limfocitopenije u bolesnika s infekcijom donjih dišnih putova (IDDP) i bolesnika s infekcijom mokraćnog sustava (IMS). Ova retrospektivna studija uključila je 52 bolesnika s IDDP i 60 bolesnika s IMS. Kontrolnu skupinu činilo je 70 zdravih osoba primljenih u ambulantu za infektivne bolesti. Nije utvrđena statistički značajna povezanost pojedinih skupina ispitanika i broja trombocita. Limfocitopeniju je imalo sedam $(11,7 \%)$ bolesnika s IMS i četiri $(7,7 \%)$ bolesnika s IDDP, ali nije bilo statistički značajne povezanosti skupina ispitanika i broja limfocita. Rezultati istraživanja ukazuju na zaključak da broj limfocita i trombocita može biti unutar normalnih granica u bolesnika s IMS, kao i u onih s IDDP.

Ključne riječi: Urinarne infekcije; Respiratorne infekcije; Trombocitoza; Limfocitoza; Trombociti, broj 